\title{
THE IMPLEMENTATION OF COOPERATIVE LEARNING TYPE THINK PAIR SHARE MODEL TO IMPROVE READING COMPREHENSION SKILL IN DISRUPTION ERA
}

\author{
Maullana Latief, Muhammad Ismail Sriyanto, Joko Daryanto \\ Universitas Sebelas Maret \\ maulanalatief95@gmail.com
}

Article History

accepted 09/07/2018

approved 01/08/2018

published 17/09/2018

\section{Keywords}

think pair share, reading comprehension, disruption era

\begin{abstract}
The purpose of this research was to improve the skill of reading comprehension by applied Think Pair Share (TPS) model in disruption era for fifth grade students in SDN Purwotomo No. 97 Surakarta on academic year of 2017/2018. The form of this research was a Classroom Action Research which conducted in two cycles. Each cycle consisted of four stages i.e. planning, action, observation, and reflection. The subjects of this research included teacher and 23 fifth grade students in SDN Purwotomo No. 97 Surakarta. The data collected by observation, interview, test, and documentation techniques. The data validity test were using content validity, triangulation of resource, and triangulation of technique.

The result of this research shows the improvement of skill of reading comprehension values from pre-action, cycle I until cycle II.
\end{abstract}

Social, Humanities, and Education Studies (SHEs): Conference Series https://jurnal.uns.ac.id/shes 


\section{PENDAHULUAN}

Era disrupsi merupakan era perubahan zaman yang memudahkan manusia dalam menggunakan teknologi untuk beraktivitas lebih cepat, mudah, dan terjangkau. Ardiansyah, R., Suharno, \& Trianto (2018) menyebutkan bahwa, "disruption is an era when technological and scientific developments have explored all aspects and classes of human life". Era disrupsi yang mana akses ke segala bentuk informasi baik yang benar atau tidak, atau yang valid atau tidak, tidak tersaring secara sempurna melalui sistem, sehingga memang membutuhkan keterampilan membaca pemahaman untuk mencapai tujuan dari membaca yang seutuhnya. Oleh karena itu, diperlukan keterampilan membaca pemahaman dalam pembelajaran berbahasa Indonesia di sekolah dasar agar siswa tidak salah melangkah dalam menghadapi era disrupsi.

Bahasa Indonesia memiliki kedudukan yang penting dalam kehidupan berbangsa dan bernegara, maka pemerintah menjadikannya salah satu mata pelajaran yang wajib dipelajari siswa. Penguasaan bahasa yang baik dapat meningkatkan berbagai keterampilan berbahasa dalam diri siswa. Keterampilan berbahasa mencakup empat segi, yaitu: (1) keterampilan menyimak/ mendengarkan (listening skills), (2) keterampilan berbicara (speaking skills), (3) keterampilan membaca (reading skills), (4) keterampilan menulis (writing skills). Salah satu keterampilan berbahasa Indonesia adalah keterampilan membaca. Keterampilan membaca merupakan keterampilan mendasar yang tidak bisa diperoleh secara alamiah, tetapi melalui proses pembelajaran intensif dengan tujuan dapat mengusai dan menambah kosakata yang bermanfaat untuk diri sendiri. Membaca juga memberikan manfaat untuk mengetahui pola pikir atau jalan pikiran orang lain. Oleh karena itu, pembelajaran membaca sangat penting dalam pendidikan sekolah dasar. Bimbingan dari guru sangat diperlukan dalam proses belajar membaca agar peserta didik dapat melatih kemampuan berpikir, meningkatkan pemahaman, menambah wawasan dan ilmu pengetahuan, membaca untuk mengasah keterampilan menulis dan keterampilan berbicara di depan umum.

Somadayo (2011:4) menyatakan membaca merupakan suatu kegiatan interaktif untuk memetik serta memahami arti atau makna yang terkandung di dalam bahan tulis. Jadi kegiatan membaca bertujuan untuk memperoleh informasi dan memahami makna bacaan yang ada pada teks. Tarigan (2008: 9) bahwa tujuan utama dalam membaca adalah untuk mencari serta memperoleh informasi, mencakup isi, dan memahami makna bacaan, sehingga dapat dikatakan bahwa untuk mendapatkan informasi dari suatu bacaan, yaitu dengan cara membaca, kemudian apa yang diambil dari proses membaca dipahami maknanya. Setelah terjadi pemahaman, maka dapat dikatakan bahwa sedang ada proses keterampilan membaca pemahaman.

Jenis-jenis membaca yang diajarkan dalam pembelajaran bahasa Indonesia di sekolah dasar yaitu membaca cepat, membaca sekilas, membaca memindai, membaca intensif, dan membaca ekstensif. Di dalam membaca intensif terdapat membaca telaah isi dan bagian dalam membaca telaah isi terdapat membaca pemahaman. Membaca pemahaman berisi tentang keterampilan siswa memahami, menyeleksi fakta, gagasan, serta menarik kesimpulan yang diperoleh dari informasi pada bacaan teks secara menyeluruh. Membaca pemahaman diajarkan pada pembelajaran bahasa Indonesia kelas V semester I dan II di sekolah dasar.

Hasil wawancara awal yang dilakukan dengan guru diperoleh bahwa adanya permasalahan pada pembelajaran bahasa Indonesia khususnya membaca 
pemahaman yang masih rendah. Permasalahan tersebut berkaitan materi membaca tentang unsur-unsur intrinsik dan menceritakan kembali isi bacaan dengan menggunakan bahasa sendiri. Hal tersebut disebabkan kurangnya latihan siswa dalam membaca bacaan dengan baik, kurang kosentrasi dalam membaca, antusias dan motivasi siswa dalam membaca yang masih kurang. Hasil wawancara tersebut didukung dengan observasi di lapangan yang menunjukkan bahwa penyebab rendahnya keterampilan membaca pemahaman yaitu pembelajaran membaca pemahaman terkesan membosankan dan guru belum menggunakan model yang inovatif. Selain itu, berdasarkan hasil tes pratindakan diperoleh hasil nilai rata-rata keterampilan membaca pemahaman siswa sebesar 48,02 dengan nilai tertinggi 87,00 dan nilai terendah 5,00 , serta ketuntasan klasikal hasil tes pratindakan keterampilan membaca pemahaman sebesar $8,70 \%$ atau hanya dua siswa yang memperoleh nilai diatas KKM yakni 75.

Fakta di atas menunjukkan kualitas proses dan hasil pembelajaran yang dilaksanakan guru masih kurang optimal. Sehubungan dengan permasalahan rendahnya keterampilan membaca pemahaman maka salah satu alternatif pemecahan masalah adalah dengan menggunakan model pembelajaran yang tepat dan mempunyai tujuan mendorong siswa berpikir kritis, aktif dalam belajar, dan pembelajaran yang bermakna. Model pembelajaran yang dipakai adalah model pembelajaran Kooperatif. Model pembelajaran Kooperatif memiliki beberapa tipe, salah satunya adalah model Kooperatif tipe Think Pair Share (TPS). Sugiarto \& Sumarsono (2014: 207) menyebutkan bahwa "The basic foundation of this model is to make the students more active in the teaching-learning process by discussing with their classmates." Penyataan tersebut memiliki arti bahwa dasar dari model ini adalah membuat siswa lebih aktif dalam proses belajar mengajar dengan berdiskusi dengan teman sekelas mereka. Adanya interaksi ini memberikan kesempatan bagi siswa untuk berpikir secara sendiri maupun bersama dengan orang lain.

Model Kooperatif tipe Think Pair Share (TPS) memiliki tiga langkah utama yang dilaksanakan dalam pembelajaran. Langkah-langkahnya yaitu think (berpikir secara individual), pair (berpasangan), dan share (berbagi jawaban dengan pasangan lain atau seluruh kelas). Pada langkah think siswa diberikan batasan waktu untuk memikirkan jawabannya secara individual terhadap pertanyaan yang diberikan, kemudian tahap pair siswa berpasangan sesuai dengan aturan yang diberikan guru dan mendiskusikan mengenai jawaban atas pertanyaan yang diberikan dansetiap siswa memiliki kesempatan untuk menyampaikan pendapatnya sehingga muncul berbagai jawaban secara bersama. Pada tahap share, siswa mempresentasikan hasil diskusinya di tahap pair kepada seluruh siswa di kelas.

Shoimin (2016: 211) menyatakan bahwa kelebihan model Kooperatif tipe Think Pair Share (TPS) antara lain: (1) TPS mudah diterapkan di berbagai jenjang pendidikan dan dalam setiap kesempatan; (2) menyediakan waktu berpikir untuk meningkatkan kualitas respons siswa; (3) siswa menjadi lebih aktif dalam berpikir mengenai konsep dalam mata pelajaran; (4) siswa lebih memahami tentang konsep topik pelajaran selama diskusi; (5) siswa dapat belajar dari siswa lain; (6) setiap siswa dalam kelompoknya mempunyai kesempatan untuk berbagi atau menyampaikan idenya. Jadi melalui model pembelajaran Kooperatif tipe Think Pair Share siswa menjadi aktif dan lebih memahami konsep suatu mata pelajaran, kemudian menyampaikan ide dari apa yang dipikirkannya. 
Berdasarkan uraian kajian tentang model pembelajaran Think Pair Share (TPS), Permasalahan yang ada dalam pembelajaran membaca, khususnya membaca pemahaman dapat diatasi dengan menerapkan model pembelajaran Kooperatif tipe Think Pair Share.

\section{METODE}

Penelitian ini berupa Penelitian Tindakan Kelas (PTK) yang dilakukan di SD Negeri Purwotomo No. 97 Surakarta pada bulan Januari-Juli 2018. Subjek penelitian ini adalah siswa kelas $V$ yang berjumlah 23 siswa, terdiri dari 11 siswa laki-laki dan 12 siswa perempuan. Semua siswa di kelas $\mathrm{V}$ memiliki kondisi fisik dan kejiwaan yang sehat, dengan kata lain tidak ada siswa yang cacat.

Teknik pengumpulan data yaitu melalui observasi, wawancara, tes, dan dokumentasi. Uji validitas data dilakukan dengan triangulasi dan validitas isi. Penelitian ini menggunakan teknik analisis data model interaktif Miles dan Huberman dalam Sugiyono (2015: 337) yang terdiri dari tiga tahap, yaitu data reduction, data display, dan conclusion drawing/verification.

Indikator kinerja penelitian ini adalah peningkatan keterampilan membaca pemahaman siswa dalam mata pelajaran Bahasa Indonesia dengan ketercapaian target $80 \%$ dari 23 siswa kelas V. Peningkatan keterampilan membaca pemahaman yang diukur malalui tes yang memiliki penilaian dari aspek: 1) Pemahaman isi teks; 2) Ketetapan organisasi isi teks; 3) Ketetapan struktur kalimat; 4) Penulisan tanda baca dan penggunaan huruf kapital; 5) Ketetapan diksi (Nurgiantoro, 2016: 414).

\section{HASIL DAN PEMBAHASAN}

Data tentang keterampilan membaca pemahaman diperoleh melalui observasi terhadap proses pembelajaran, hasil wawancara dengan guru kelas $\mathrm{V}$, dan tes pratindakan tentang keterampilan membaca pemahaman pada siswa kelas $\mathrm{V}$ SD Negeri Purwotomo No. 97 Surakarta. Observasi yang dilakukan mendapatkan hasil bahwa pembelajaran bahasa Indonesia khususnya membaca pemahaman yang masih rendah. Hasil tersebut dikarenakan pembelajaran membaca pemahaman yang terkesan membosankan dan belum menggunakan model yang inovatif. Observasi tersebut dikuatkan dengan wawancara guru kelas $\mathrm{V}$, menyatakan bahwa siswa mengalami kesulitan dalam membaca pemahaman.

Hasil dari tes pratindakan menunjukkan bahwa hasil keterampilan membaca pemahaman pada siswa kelas $\mathrm{V}$ masih tenggolong rendah. Penilaian tes pratindakan meliputi menyebutkan unsur intrinsik dan membuat simpulan isi cerita dengan bahasa sendiri. Berikut ini disajikan Tabel 1 mengenai distribusi frekuensi nilai tes pratindakan keterampilan membaca pemahaman cerita anak pada siswa kelas V SD Negeri Purwotomo No. 97 Surakarta. 
Tabel 1. Distribusi Frekuensi Nilai Tes Pratindakan Keterampilan Membaca Pemahaman Cerita Anak

\begin{tabular}{|c|c|c|c|c|c|c|}
\hline \multirow[t]{2}{*}{ No } & \multirow[t]{2}{*}{ Interval nilai } & \multirow{2}{*}{$\begin{array}{c}\text { Frekuensi } \\
\text { (fi) }\end{array}$} & \multirow{2}{*}{$\begin{array}{c}\text { Nilai } \\
\text { tengah } \\
(x i)\end{array}$} & \multirow[t]{2}{*}{ fi.xi } & \multicolumn{2}{|c|}{ Persentase \% } \\
\hline & & & & & Relatif & Komulatif \\
\hline 1 & $5-18$ & 2 & 11,5 & 23 & 8,70 & 8,70 \\
\hline 2 & $19-32$ & 5 & 25,5 & 127,5 & 21,74 & 30,43 \\
\hline 3 & $33-46$ & 4 & 39,5 & 158 & 17,39 & 47,83 \\
\hline 4 & $47-60$ & 3 & 53,5 & 160,5 & 13,04 & 60,87 \\
\hline 5 & $61-74$ & 7 & 67,5 & 472,5 & 30,43 & 91,30 \\
\hline 6 & $75-88$ & 2 & 81,5 & 163 & 8,70 & 100,00 \\
\hline \multicolumn{2}{|r|}{ Jumlah } & 23,00 & & 1104,5 & & \\
\hline \multicolumn{2}{|r|}{ Rata-rata } & \multicolumn{5}{|c|}{48,02} \\
\hline \multicolumn{2}{|c|}{ Nilai Tertinggi } & \multicolumn{5}{|c|}{87,00} \\
\hline \multicolumn{2}{|c|}{ Nilai terendah } & \multicolumn{5}{|c|}{5,00} \\
\hline \multicolumn{2}{|c|}{ Ketuntasan klasikal } & \multicolumn{5}{|c|}{8,70} \\
\hline \multicolumn{2}{|c|}{ Nilai dibawah KKM } & \multicolumn{5}{|c|}{91,30} \\
\hline
\end{tabular}

Tabel 1 menunjukkan bahwa hasil keterampilan membaca pemahaman pada pratindakan diperoleh ketuntasan klasikal sebesar 8,70\% atau hanya dua siswa yang memperoleh nilai di atas KKM yakni 75

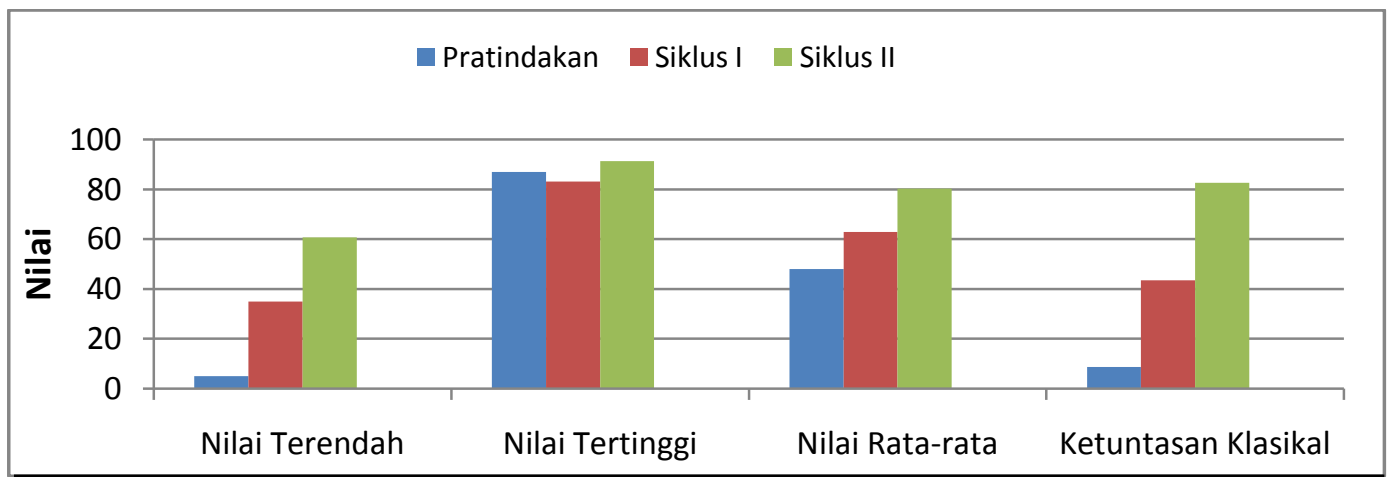

\section{Gambar 1. Grafik Perbandingan Hasil Keterampilan Membaca Pemahaman Siswa Antarsiklus}

Tabel 1 menunjukkan penerapan model pembelajaran Think Pair Share memberikan dampak positif bagi siswa selama pembelajaran membaca pemahaman. Sejalan dengan pendapat Bloom dalam Papatga, E \& Ali Ersoy (2016) bahwa, "Students' achievement in reading comprehension forms the base for their success in other courses." Diartikan bahwa prestasi siswa dalam membaca pemahaman merupakan dasar kesuksesan mereka di mata pelajaran lain. Oleh karena itu, membaca pemahaman merupakan kunci untuk meraih kesuksesan dalam pembelajaran bahasa Indonesia khususnya dan mata pelajaran lainnya.

Penelitian dengan menerapkan model pembelajaran Think Pair Share pada siklus I, guru sudah berusaha menciptakan kondisi pembelajaran dengan baik, namun masih juga ada kendala yang dihadapinya. Kendalanya yaitu penguasaan 
pembelajaran belum sesuai dengan alokasi waktu yang direncanakan. Sedangkan permasalahan pada siswa yaitu (1) siswa belum aktif dan antusias pada pembelajaran, dibuktikan dengan belum beraninya siswa berpendapat; (2) diskusi dengan anggota kelompok belum maksimal karena siswa masih ada yang belum berani menyampaikan idenya; (3) beberapa siswa belum ada keberanian untuk menceritakan kembali isi teks. Permasalahan siklus I diperbaiki pada siklus II dengan memberikan motivasi kepada siswa untuk lebih berani lagi dalam berdiskusi dan berpendapat dihadapan temantemannya.

Proses pembelajaran pada siklus II berhasil karena dapat meningkatkan keterampilan membaca pemahaman siswa kelas V SD Negeri Purwotomo No. 97 Surakarta. Hal tersebut dibuktikan dengan siswa menunjukkan keaktifan dan keantusiasan yang baik dalam mengikuti pembelajaran. Siswa berani dalam berdiskusi dan berpendapat dengan teman-temannya. Sikap yang baik juga ditunjukkan siswa dalam membaca teks bacaan dengan berkosentrasi ketika membaca dan tanpa bersuara pada siklus II. Siswa juga diberikan waktu dalam berfikir untuk menjawab pertanyaan dari guru. Hal ini sesuai pendapat Siswanto \& Arini (2016: 79-80) mengenai kelebihan model pembelajaran Kooperatif Think Pair Share (TPS) yaitu memberi waktu lebih banyak kepada siswa untuk berpikir, menjawab, dan saling membantu satu sama lain. Diberikannya waktu dalam berfikir digunakan siswa dengan baik. Kegiatan LKPD dilakukan siswa dengan berpasangan. siswa menjawab secara individu terlebih dahulu kemudian jawaban tersebut dijadikan satu dengan pasangannya. Selanjutnya setelah tahap berpasangan, siswa membagikan jawabannya kedalam kelompok. Penerapan model pembelajaran Think Pair Share membuat siswa lebih aktif dalam belajar mengajar. Hal ini sesuai dengan pendapat Sugiarto \& Sumarsono (2014: 207) menyebutkan bahwa "The basic foundation of this model is to make the students more active in the teaching-learning process by discussing with their classmates." Penyataan tersebut memiliki arti bahwa dasar dari model ini adalah membuat siswa lebih aktif dalam proses belajar mengajar dengan berdiskusi dengan teman sekelas mereka.

Pengerjaan LKPD dengan teman pasangan dirubah dari pertemuan ke pertemuan. Jadi, siswa akan mendapatkan pasangan yang berbeda-beda. Siswa yang pasif dalam berdiskusi dipasangkan dengan siswa yang aktif berdiskusi. Hal ini sesuai pendapat Trianto (2010) dalam Alpusari \& Putra (2013: 2806) menyebutkan bahwa “ TPS is a cooperative learning that is designed to influence the pattern of student interaction and is an effective way to create an atmosphere variation pattern class discussion, with the assumption that all the recitation and discussion requires setting in the control of the class as a whole." Pernyatan tersebut memiliki arti bahwa "TPS adalah pembelajaran Kooperatif yang dirancang untuk mempengaruhi pola interaksi siswa dan cara yang efektif untuk menciptakan suasana variasi pola diskusi kelas, dengan asumsi bahwa semua pembacaan dan pengaturan diskusi diperlukan dalam pengendalian kelas secara keseluruhan.

Proses pembelajaran pada siklus II berhasil karena mampu meningkatkan keterampilan membaca pemahaman siswa kelas V SD Negeri Purwotomo No. 97 Surakarta. Dibuktikan dari hasil keterampilan membaca pemahaman siswa kelas V SD Negeri Purwotomo No. 97 diketahui adanya peningkatan yang signifikan antara sebelum dan sesudah penerapan model pembelajaran Think Pair Share. Peningkatan keterampilan membaca pemahaman terbukti dari ketuntasan klasikal keterampilan membaca pemahaman pada pratindakan yaitu 8,70\% atau 2 dari 23 siswa yang 
terampil, siklus I sebesar $43,48 \%$ atau 10 dari 23 siswa yang terampil, dan siklus II sebesar $82,61 \%$ atau 19 dari 23 siswa yang terampil. Data yang diperoleh secara keseluruhan indikator kinerja penelitian telah tercapai pada siklus II, namun masih terdapat 4 siswa yang berada dalam kategori cukup terampil atau nilainya di bawah KKM. Siswa yang cukup terampil tersebut memiliki kesalahan dalam pemahaman isi teks dan ketetapan organisasi isi teks yang dalam menjawab masih belum lengkap. Selain itu, masih ada penulisan tanda baca dan penggunaan huruf kapital yang belum tepat. Berdasarkan hasil analisis data dan pembahasan dapat disimpulkan bahwa penerapan model pembelajaran Kooperatif Think Pair Share dapat meningkatkan keterampilan membaca pemahaman siswa kelas V SD Negeri Purwotomo No. 97 Surakarta tahun ajaran 2017/2018 di era disrupsi.

\section{SIMPULAN}

Hasil penelitian tindakan kelas mengenai penerapan model pembelajaran Think Pair Share yang dilakukan dalam dua siklus dalam pembelajaran bahasa Indonesia, dapat disimpulkan bahwa penerapan model pembelajaran Think Pair Share dapat meningkatkan keterampilan membaca pemahaman pada siswa kelas V SD Negeri Purwotomo No. 97 Surakarta tahun ajaran 2017/2018. Penerpan model pembelajaran Think Pair Share dapat dikemukakan implikasi teori dan implikasi praktis. Implikasi teoritis dari penelitian ini yaitu penerapan model pembelajaran Think Pair Share dapat meningkatkan pembelajaran bahasa Indonesia khususnya keterampilan membaca pemahaman siswa kelas $\mathrm{V}$. Hasil penelitian dengan penerapan model pembelajaran Think Pair Share dan keterampilan membaca pemahaman dapat dijadikan referensi pada penelitian sejenis dalam melaksanakan kegiatan pembelajaran. Oleh karena itu, keterampilan membaca pemahaman secara berkalantujan dikembangkan dengan menerapkan model pembelajaran Think Pair Share. Implikasi praktisnya adalah penerapan model pembelajaran Think Pair Share yang sudah terbukti dapat meningkatkan keterampilan membaca pemahaman siswa kelas V. Selain itu, penerapan model tersebut dapat meningkatkan aktivitas siswa dalam pembelajaran karena melatih siswa dalam berfikir, bertukar pikiran, dan berani dalam menyampaikan pendapatnya. Penerapan model pembelajaran Think Pair Share lebih efektif dan efisien untuk mengatasi permasalahan sejenis, serta dapat digunakan pada semua mata pelajaran dengan disesuaikan permasalahan yang dijumpai di era distrupsi.

\section{DAFTAR PUSTAKA}

Alpusari, M \& Riki, A.P. (2013). The Application of Cooperative Learning Think Pair Share (TPS) Model to Increase the Process Science Skills in Class IV Elementry School Number 81 Pekanbaru City. International Journal of Science and Research (IJSR), 6,14, ISSN 2319-7064.

Ardiansyah, R., Suharno, \& Trianto. (2018). Inheritance Nasional Culture Through Learning in Elementary School at Disruptive Era: Case Study in Surakarta Indonesia. Internastional Journal of Educational Research Revies (IJERE).

Nurgiyantoro, Burhan. (2016). Penilaian Pembelajaran Bahasa Indonesia Berbasis Kompetensi. Yogyakarta: BPFE-YOGYAKARTA.

Papatga, E \& Ali Ersoy. (2016). Improving Reading Comprehension Skills Through the SCRATCH Program. International Electric Journal of Elementary Education, ISSN: 1307-9298. 
Shoimin, A. (2016). 68 Model Pembelajaran Inovatif dalam Kurikulum 2013. Yogyakarta: Ar-Ruzz Media.

Siswanto, Wahyudi \& Dewi Ariani. (2016). Model Pembelajaran Menulis Cerita: Buku Panduan Guru Ketika Mengajar Menulis Cerita. Malang: Refika Aditama.

Somadayo, Samsu. (2011). Strategi dan Teknik Pembelajaran. Yogyakarta: Graha IImu.

Sugiarto, D \& Puji Sumarsono. (2014). The Implementation of Think-Pair-Share Model to Improve Students' Ability in Reading Narrative Texts. International Journal of English and Education, 3 (3), ISSN 2278-4012.

Sugiyono. (2015). Metode Penelitian Pendidikan: Pendekatan Kuantitatif, Kualitatif, dan $R \& D$. Bandung: Alfabeta.

Tarigan, Henry Guntur. (2008). Membaca: sebagai Suatu Keterampilan Berbahasa. Bandung: Angkasa. 